\title{
Colletotrichum fioriniae and Colletotrichum godetiae Causing Postharvest Bitter Rot of Apple in South Tyrol (Northern Italy)
}

\author{
Greice Amaral Carneiro and Sanja Baric ${ }^{\dagger}$ \\ Faculty of Science and Technology, Free University of Bozen-Bolzano, 39100 Bozen-Bolzano, Italy
}

\begin{abstract}
South Tyrol (northern Italy) harbors one of the largest interconnected apple farming areas in Europe, contributing approximately $10 \%$ to the apple production of the European Union. Despite the availability of sophisticated storage facilities, postharvest diseases occur, one of which is bitter rot of apple. In Europe, this postharvest disease is mainly caused by the Colletotrichum acutatum species complex. This study aimed to characterize the Colletotrichum spp. isolated from decayed apple fruit collected in 2018 and 2019 in South Tyrol. The characterization of Colletotrichum spp. was accomplished based on multilocus DNA sequences of four different genomic regions-actin (ACT), glyceraldehyde-3-phosphate dehydrogenase (GAPDH), histone H3 (HIS3), and the internal transcribed spacer (ITS) region-as well as morphological and pathogenicity assessment. A phylogenetic analysis based on multilocus DNA sequences showed that the isolates obtained from apples with symptoms of bitter rot belonged to the species Colletotrichum god-

belonging to the same species complex, Colletotrichum salicis, was described in this area. Moreover, the Colletotrichum isolates found in this study proved to be virulent on Cripps Pink, Golden Delicious, and Roho 3615/Evelina. To the best of our knowledge, $C$. godetiae and $C$. fioriniae have so far never been mentioned as postharvest pathogens of apple in Italy, although the reanalysis of samples collected in the past indicates that these pathogens have been occurring in Italy for at least a decade. So far, bitter rot seems to play a minor role as a postharvest disease in South Tyrol, but it was disproportionately represented on a few scab-resistant apple cultivars, which are increasingly planted in organically managed orchards. Considering that the expansion of organic apple production and the conversion to new potentially Colletotrichum-susceptible cultivars will continue, the present study represents an important contribution toward a better understanding of bitter rot in this geographic area.
\end{abstract} etiae and Colletotrichum fioriniae, which are part of the Colletotrichum acutatum species complex. A third species isolated from apples
Keywords: fungi, fruit, tree fruits, etiology, pathogen diversity
Colletotrichum acutatum and Colletotrichum gloeosporioides species complexes (SCs) have been associated with bitter rot of apple (Malus domestica Borkh.) all over the world. However, the C. acutatum SC is considered to be more prevalent in Europe (Grammen et al. 2019) and comprises species of pathogenic fungi, which cause the most significant losses during the vegetative stage in the orchard. In warmer climates, $C$. acutatum SC infects apple fruits during the summer growing period, in which the first symptoms can become visible as small, black spots that later become depressed and expand to form tan to dark-brown or black, usually circular lesions. Finally, salmon-orange spores are formed in acervuli that arise concentrically from the center of the lesion while the fruits are still on the trees. However, in cooler growing areas, probably because of climatic effects, this SC is more often noticed as a latent pathogen; it does not induce any symptoms at harvest, but the development of rot occurs during storage (Sutton et al. 2014; Wenneker and Thomma 2020; Wharton and DiéguezUribeondo 2004).

Multilocus sequence typing (MLST), which is based on the analysis of several protein-coding genes, in addition to the internal transcribed spacer (ITS) region, has become widely accepted as a tool for DNA

${ }^{\dagger}$ Corresponding author: S. Baric; sanja.baric@unibz.it

Funding: The Free University of Bozen/Bolzano provided funding for the project "Development of a decision support system for the determination of postharvest disorders and diseases of apples-DSSApple" (project code IN2067 - ID Call 2017).

*The $\boldsymbol{e}$-Xtra logo stands for "electronic extra" and indicates there are six supplementary figures and seven supplementary tables published online.

The author(s) declare no conflict of interest.

Accepted for publication 21 February 2021.

Copyright $\odot 2021$ The Author(s). This is an open access article distributed under the CC BY 4.0 International license. barcoding and species identification (Taylor and Fisher 2003). In 2012, Damm et al. (2012) performed a taxonomic revision based principally on multilocus phylogenetic data, in which the $C$. acutatum SC was subdivided into $>30$ species, confirming the existence of at least nine distinct molecular genetic groups (A1 to A9) proposed by Sreenivasaprasad and Talhinhas (2005). To name some species of these genetic groups associated with bitter root of apple, A3 group was described as Colletotrichum fioriniae, A4 as Colletotrichum godetiae (syn. Colletotrichum clavatum), and A7 as Colletotrichum salicis (Amaral Carneiro et al. 2021; Damm et al. 2012; Faedda et al. 2011; Grammen et al. 2019; Shivas and Tan 2009). To distinguish the species within the $C$. acutatum $\mathrm{SC}$, different gene regions can be analyzed. Generally, actin (ACT), glyceraldehyde-3-phosphate dehydrogenase (GAPDH), histone H3 (HIS3), chitin synthase 1 (CHS-1), and $\beta$-tubulin (TUB2) gene regions are considered to represent suitable markers to characterize the $C$. acutatum SC (Damm et al. 2012; Weir et al. 2012). In recent years, two species of the $C$. acutatum $\mathrm{SC}, C$. fioriniae and $C$. godetiae, were recognized as the most important pathogens causing bitter rot of apple in Europe (Baroncelli et al. 2014; Børve and Stensvand 2015; Grammen et al. 2019; Munda 2014; Nodet et al. 2016). These two species show distinct morphological features, such as differences in the shape and size of conidia, in the color of colonies, and in the growth rates of the mycelium. In addition, $C$. godetiae proved to be more aggressive in the infection of apple fruit (Grammen et al. 2019). C. salicis is another species of the C. acutatum $\mathrm{SC}$ associated with bitter rot of apple in Europe, although so far it has been reported in few studies (Amaral Carneiro et al. 2021; Grammen et al. 2019)

South Tyrol (northern Italy) harbors the largest interconnected apple-producing area in Europe. Approximately 974,000 metric tons of apple were produced on 18,333 hectares (ha) of land in 2019 (Autonomous Province of Bozen/Bolzano 2020). Over the past years, researchers in European countries such as Belgium, England, France, The Netherlands, Norway, and Slovenia have published several reports describing the emergence of species of the C. acutatum SC that have not been associated with bitter rot of apple in the past (Baroncelli et al. 2014; Børve and Stensvand 2015; Grammen et al. 2019; Munda 2014; 
Nodet et al. 2016; Wenneker et al. 2016). However, thus far no scientific information is available about the Colletotrichum spp. causing bitter rot of apple in South Tyrol, which harvests approximately 10\% of the total apple production in the European Union. Therefore, the main objective of this study was to collect apples with postharvest symptoms of bitter rot from several packinghouses in South Tyrol and perform phenotypic and molecular genetic characterization of the isolates identified as Colletotrichum spp. Furthermore, pathogenicity assays were performed with selected isolates. These results will lead to an increased understanding of the causative agents of bitter rot of apple in this region and northern Italy and will provide a foundation for developing specific diagnostic methods and implementing disease management strategies.

\section{Materials and Methods}

Sampling and isolation of postharvest pathogens of apple. In 2018 and 2019, collection of apples with decay symptoms was conducted after 6 to 8 months of storage under controlled conditions in six packinghouses representing different cultivation areas in the Autonomous Province of Bozen/Bolzano, such as Eisacktal/Valle Isarco, the area around Bozen/Bolzano, Unterland/Bassa Atesina, the area around Meran/Merano, and Vinschgau/Val Venosta. Four packinghouses stored apples grown by following integrated production standards, one packinghouse specialized in organic apples, and one packinghouse had separate lines for the storage of apples derived from organic and integrated production. Whereas first-year sampling involved apples that displayed any kind of postharvest disease, second-year sampling focused on so-called Gloeosporium SC (Giraud 2012), which traditionally comprises several species of the genera Neofabraea spp. and Colletotrichum spp.

More than 1,000 apple fruits that were inspected for the presence of symptoms of postharvest diseases were taken to the laboratory for microbiological isolation to determine the pathogens involved in the disease. A photo setup was established to document external and internal symptoms during the process of pathogen isolation. Rotten apples were washed with curd soap, rinsed well with tap water, and cleaned with ethanol. From each apple, four transplants from the border between healthy and diseased pulp tissue were dissected and transferred to a Petri dish containing potato dextrose agar (PDA; VWR BDH Chemicals, Poole, UK) nutrient medium. The cultures were incubated in the laboratory at room temperature (approximately $24^{\circ} \mathrm{C}$ ), and fungal growth was observed after 14 days. Of the 740 fungal cultures that were isolated in 2018 and 331 that were obtained in 2019, 19 isolates were identified as Colletotrichum spp. based on morphological features on PDA and DNA sequencing of the ITS region. Once the cultures were identified as belonging to the genus Colletotrichum, monosporic cultures were prepared by adapting the procedure described by Choi et al. (1999) (Amaral Carneiro and Baric 2021). Three additional Colletotrichum isolates obtained from apple fruit and leaf spots in previous years in South Tyrol were included in this study. To store the isolates, small blocks of medium that contained mycelium were excised and conserved in slant culture tubes on malt agar (Biolab, Budapest, Hungary) at $4^{\circ} \mathrm{C}$. All isolates characterized in the present study are reported in Table 1.

DNA-based analysis. The 22 pure cultures identified as Colletotrichum spp. were transferred on fresh PDA medium and incubated at $24^{\circ} \mathrm{C}$ for 2 weeks to obtain sufficient amounts of mycelium for DNA isolation. The DNA extraction protocol of Cassago et al. (2002) was followed, with some modifications. The mycelium was harvested from the growth medium with a sterile blade and was placed in a 2-ml microcentrifuge tube containing $500 \mu \mathrm{l}$ of lysis buffer $(50 \mathrm{mM}$ Tris-HCl, pH 7.5; 10 mM EDTA; 1\% sodium dodecyl sulfate). Subsequently, two 3-mm tungsten carbide beads (Qiagen, Hilden, Germany) were added to the 2-ml tube, which was then mixed vigorously at a frequency of $30 \mathrm{~Hz}$ in the TissueLyser II (Qiagen, Hilden, Germany) for $2 \mathrm{~min}$ and left to rest for $1 \mathrm{~min}$ on ice. This step was followed by protein precipitation with potassium acetate $(\mathrm{pH} 4.8)$, avoiding the use of phenol-chloroform. DNA was precipitated with isopropanol and washed with $70 \%$ ethanol, and the pellet was dried under laminar flow. Finally, the DNA was resuspended in $30 \mu \mathrm{l}$ of Tris-EDTA-Buffer (pH 8), and DNA quantity and quality were assessed with a DeNovix DS-11 Spectrophotometer (DeNovix Inc., Wilmington, DE).
To identify the Colletotrichum isolates at the species level, PCR amplifications with specific primers were performed for the ACT (Carbone and Kohn 1999), GAPDH (Guerber et al. 2003), and HIS3 (Crous et al. 2004) gene regions in addition to the ITS region (Lévesque and de Cock 2004). Each PCR reaction contained $7.5 \mu \mathrm{l}$ of the 2x PCRBIO Taq Mix (PCR Biosystems Ltd., Oxford, United Kingdom), which contains a premix of Taq DNA polymerase, dNTPs and the appropriate buffer system, $0.75 \mu \mathrm{l}$ of each forward and reverse primer $(5 \mu \mathrm{M})$, and $5 \mu \mathrm{l}$ of sterile, nuclease-free water. The final volume of the PCR reaction of $15 \mu \mathrm{l}$ was reached by the addition of $1 \mu \mathrm{l}$ of template DNA (initial concentration of $10 \mathrm{ng} \mu \mathrm{l}^{-1}$ ). The PCR conditions were as follows: an initial denaturation step of $2 \mathrm{~min}$ at $95^{\circ} \mathrm{C}$, followed by 35 cycles of $95^{\circ} \mathrm{C}$ for $30 \mathrm{~s}$, the primer-specific annealing temperature for $30 \mathrm{~s}$ (Table 2) and $72^{\circ} \mathrm{C}$ for $45 \mathrm{~s}$, and a final extension step of $7 \mathrm{~min}$ at $72^{\circ} \mathrm{C}$. In addition to the annealing temperatures, Table 2 indicates the expected amplicon lengths produced by each pair of primers. PCR products were separated and visualized on agarose gels stained with MIDORI Green (NIPPON Genetics, Saitama, Japan). All PCR products displaying sharp and distinct bands of the expected size were purified with the A'SAP PCR clean-up reagents (ArticZymes, Troms $\varnothing$, Norway) and sent for Sanger sequencing with the forward primer to Microsynth Seqlab GmbH (Göttingen, Germany). To confirm each distinct DNA sequence, selected PCR products were also sequenced with the reverse primers. Raw sequence data were controlled and aligned by using the Clustal Omega alignment tool implemented in the software program Geneious Prime, version 2019.2 (Biomatters Ltd., Auckland, New Zealand).

To identify the Colletotrichum isolates, all sequences were subjected to nucleotide basic local alignment search tool (BLASTn) analysis (National Center for Biotechnology Information, Bethesda, MD) (Boratyn et al. 2013). All the sequences generated in this study were deposited in GenBank; accession numbers can be found in Table 1. Sequences of the same set of genomic regions as analyzed in the present study of 35 reference isolates representing different species of the genus were selected from the works of Da Lio et al. (2018) and Damm et al. (2012) to perform phylogenetic analyses (Supplementary Table S1). The phylogenetic analyses were accomplished for each gene separately (data not shown because each genomic region provided the same topology) and for a multilocus concatenated alignment combining four genes (ACT, GAPDH, HIS3, and ITS) using the maximum likelihood algorithm as implemented in the software Molecular Evolutionary Genetic Analysis (MEGA X) (Kumar et al. 2018). The alignment comprised all the sequences obtained in the present study and the sequences of the reference isolates, whereas $C$. lindemuthianum was used as an outgroup. Ambiguously aligned regions were excluded from analyses. Branch-support values for each tree obtained by maximum likelihood analysis were assessed by bootstrapping with 1,000 replications.

Morphological characterization. Morphological assessment based on in vitro growth rates and colony morphology was conducted with 19 Colletotrichum spp. isolates. A 5-mm mycelial plug of an actively growing colony was excised and placed in the center of a fresh Petri dish with PDA medium, sealed with Parafilm (Beemis, Neenah, WI), and incubated at $20^{\circ} \mathrm{C}$ for 2 weeks in the dark. Four technical replicates were prepared for each isolate. Colony diameter (two perpendicular diameters) was measured after 3, 5, 7, 10, and 14 days and the mycelial area $\left(A=\pi r^{2}\right)$ was calculated. The experiment was performed twice, with 4 weeks' time separation. Colony color was evaluated visually after 14 days. To compare conidia shape and size, two isolates of C. fioriniae (18-DSS-BS-CF-1-002 and 18-DSS-BS-NTO-1-010) and two isolates of $C$. godetiae (18-DSS-BS-EL-1-016 and 18-DSS-BSEL-1-028) were selected. A conidial spore suspension was made by flooding the Petri dishes with $3 \mathrm{ml}$ of distilled water, scraping over the mycelium, and filtering the solution through a sterile gauze. The conidial spore suspension was diluted with distilled water until a spore concentration of $10^{4}$ conidia $\mathrm{ml}^{-1}$ was obtained. For each isolate, the length and width of 80 randomly selected conidia were measured using an optical microscope coupled to a digital camera (Leica DMLS, Leica Microsystems, Wetzlar, Germany) with DeltaPix Insight software version 3.2.X (DeltaPix, Smorum, Denmark). The software was calibrated with a micrometer-measuring scale. Conidia were 
classified according to Damm et al. (2012) and Velho et al. (2015) as cylindrical or obclavate.

Statistical analyses were performed on the quantitative morphological features (which excluded colony color and shape of conidia) to test for differences between the isolates. Before a one-way analysis of variance (ANOVA), homogeneity of variances was checked for each dataset. Pairwise comparisons were performed using a post hoc Tukey HSD test. All statistical analyses were performed using R Statistical Software (R Development Core Team 2019).

An enzymatic characterization with the APIZYM assay (Bio-Merieux SA, Paris, France) was performed for selected isolates to assess the extracellular activity of 19 enzymes: alkaline phosphatase, esterase (C4), esterase lipase (C8), lipase (C14), leucine arylamidase, valine arylamidase, cystine arylamidase, trypsin, a-chymotrypsin, acid phosphatase, naphthol-AS-BI-phosphohydrolase, $\alpha$-galactosidase, $\beta$-galactosidase, $\beta$-glucuronidase, $\alpha$-glucosidase, $\beta$-glucosidase, $\mathrm{N}$-acetyl- $\beta$-glucosaminidase, $\alpha$-mannosidase, and $\alpha$-fucosidase. Two representative isolates of $C$. fioriniae (18-DSS-BS-CF-1-002 and 18-DSS-BS-NTO-1-010) and two isolates of $C$. godetiae (18-DSS-BSEL-1-016 and 18-DSS-BS-EL-1-028) were selected for this analysis. Small pieces of fungal PDA cultures were transferred to $30 \mathrm{ml}$ of potato dextrose broth (Biolab, Budapest, Hungary), and the cultures were

Table 1. Isolates of Colletotrichum spp. obtained from apples with symptoms of bitter rot that were collected from packinghouses in South Tyrol in 2018 and 2019 and obtained in previous years at the Laimburg Research Centre

\begin{tabular}{|c|c|c|c|c|c|c|c|c|c|c|}
\hline \multirow[b]{2}{*}{ No. } & \multirow{2}{*}{$\begin{array}{c}\text { Sample } \\
\text { code }\end{array}$} & \multirow{2}{*}{$\begin{array}{l}\text { Apple } \\
\text { cultivar }\end{array}$} & \multirow{2}{*}{$\begin{array}{l}\text { Fungal } \\
\text { species }\end{array}$} & \multirow[b]{2}{*}{ Year } & \multirow{2}{*}{$\begin{array}{c}\text { Apple } \\
\text { growing area }\end{array}$} & \multirow{2}{*}{$\begin{array}{c}\text { Farming } \\
\text { practice }\end{array}$} & \multicolumn{4}{|c|}{ GenBank accession numbers ${ }^{\mathrm{a}}$} \\
\hline & & & & & & & ACT & GAPDH & HIS3 & ITS \\
\hline 1 & 18-DSS-BS-CF-1-002 & Coop 38/Gold Rush & $\begin{array}{l}\text { Colletotrichum } \\
\text { fioriniae }\end{array}$ & 2018 & Meran/Merano & Organic & MT980849 & MT980873 & MT980892 & MT812218 \\
\hline 2 & 18-DSS-BS-EL-1-012 & Roho 3615/Evelina & $\begin{array}{l}\text { Colletotrichum } \\
\text { salicis }\end{array}$ & 2018 & $\begin{array}{l}\text { Unterland/Bassa } \\
\text { Atesina }\end{array}$ & Organic & MT347599* & MT347600* & MT347598* & MT33738* \\
\hline 3 & 18-DSS-BS-EL-1-016 & Roho 3615/Evelina & $\begin{array}{l}\text { Colletotrichum } \\
\text { godetiae }\end{array}$ & 2018 & $\begin{array}{l}\text { Unterland/Bassa } \\
\text { Atesina }\end{array}$ & Organic & MT980859 & MT980875 & MT980899 & MT812203 \\
\hline 4 & 18-DSS-BS-EL-1-022 & Roho 3615/Evelina & $\begin{array}{l}\text { Colletotrichum } \\
\text { godetiae }\end{array}$ & 2018 & $\begin{array}{l}\text { Unterland/Bassa } \\
\text { Atesina }\end{array}$ & Organic & MT980866 & MT980888 & МT980908 & MT812204 \\
\hline 5 & 18-DSS-BS-EL-1-023 & Roho 3615/Evelina & $\begin{array}{l}\text { Colletotrichum } \\
\text { godetiae }\end{array}$ & 2018 & $\begin{array}{l}\text { Unterland/Bassa } \\
\text { Atesina }\end{array}$ & Organic & MT980860 & MT980876 & MT980906 & MT812205 \\
\hline 6 & 18-DSS-BS-EL-1-028 & Roho 3615/Evelina & $\begin{array}{l}\text { Colletotrichum } \\
\text { godetiae }\end{array}$ & 2018 & $\begin{array}{l}\text { Unterland/Bassa } \\
\text { Atesina }\end{array}$ & Organic & MT980858 & MT980885 & МT980909 & MT812206 \\
\hline 7 & 18-DSS-BS-EL-1-031 & Roho 3615/Evelina & $\begin{array}{l}\text { Colletotrichum } \\
\text { godetiae }\end{array}$ & 2018 & $\begin{array}{l}\text { Unterland/Bassa } \\
\text { Atesina }\end{array}$ & Organic & MT980861 & MT980877 & MT980895 & MT812207 \\
\hline 8 & 18-DSS-BS-EL-1-032 & Roho 3615/Evelina & $\begin{array}{l}\text { Colletotrichum } \\
\text { godetiae }\end{array}$ & 2018 & $\begin{array}{l}\text { Unterland/Bassa } \\
\text { Atesina }\end{array}$ & Organic & MT980862 & MT980878 & МT980900 & MT812208 \\
\hline 9 & 18-DSS-BS-EL-1-033 & Roho 3615/Evelina & $\begin{array}{l}\text { Colletotrichum } \\
\text { godetiae }\end{array}$ & 2018 & $\begin{array}{l}\text { Unterland/Bassa } \\
\text { Atesina }\end{array}$ & Organic & MT980863 & MT980886 & MT980907 & MT812209 \\
\hline 10 & 18-DSS-BS-LF-1-001 & Coop 38/Gold Rush & $\begin{array}{l}\text { Colletotrichum } \\
\text { fioriniae }\end{array}$ & 2018 & Meran/Merano & Organic & MT980850 & MT980869 & МT980891 & MT812215 \\
\hline 11 & 18-DSS-BS-LF-1-005 & Coop 38/Gold Rush & $\begin{array}{l}\text { Colletotrichum } \\
\text { fioriniae }\end{array}$ & 2018 & Meran/Merano & Organic & MT980851 & МT980872 & МT980893 & MT812216 \\
\hline 12 & 18-DSS-BS-NTO-1-010 & SQ 159/Natyra & $\begin{array}{l}\text { Colletotrichum } \\
\text { fioriniae }\end{array}$ & 2018 & Meran/Merano & Organic & MT980852 & MT980870 & MT980894 & MT812217 \\
\hline 13 & 19-DSS-BS-EL-2-001 & Roho 3615/Evelina & $\begin{array}{l}\text { Colletotrichum } \\
\text { godetiae }\end{array}$ & 2019 & $\begin{array}{l}\text { Eisacktal/Valle } \\
\text { Isarco }\end{array}$ & Organic & MT980864 & MT980879 & MT980896 & MT812210 \\
\hline 14 & 19-DSS-BS-EL-2-010 & Roho 3615/Evelina & $\begin{array}{l}\text { Colletotrichum } \\
\text { godetiae }\end{array}$ & 2019 & $\begin{array}{l}\text { Eisacktal/Valle } \\
\text { Isarco }\end{array}$ & Organic & MT980865 & MT980880 & МT980904 & MT812211 \\
\hline 15 & 19-DSS-BS-EL-2-019 & Roho 3615/Evelina & $\begin{array}{l}\text { Colletotrichum } \\
\text { godetiae }\end{array}$ & 2019 & Meran/Merano & Organic & MT980867 & MT980887 & МT980901 & MT812212 \\
\hline 16 & 19-DSS-BS-3-001 & Roho 3615/Evelina & $\begin{array}{l}\text { Colletotrichum } \\
\text { godetiae }\end{array}$ & 2019 & Meran/Merano & Organic & MT980855 & MT980883 & MT980903 & MT812199 \\
\hline 17 & 19-DSS-BS-3-002 & Roho 3615/Evelina & $\begin{array}{l}\text { Colletotrichum } \\
\text { godetiae }\end{array}$ & 2019 & Meran/Merano & Organic & MT980868 & MT980889 & MT980910 & MT812200 \\
\hline 18 & 18-DSS-CAFA-DEC & Golden Delicious & $\begin{array}{l}\text { Colletotrichum } \\
\text { godetiae }\end{array}$ & 2018 & Meran/Merano & Integrated & MT980857 & MT980874 & MT980897 & MT812202 \\
\hline 19 & 18-DSS-BS-DEC & Roho 3615/Evelina & $\begin{array}{l}\text { Colletotrichum } \\
\text { godetiae }\end{array}$ & 2018 & Meran/Merano & Organic & MT980856 & MT980884 & MT980898 & MT812198 \\
\hline 20 & Lb 215/08 & Granny Smith & $\begin{array}{l}\text { Colletotrichum } \\
\text { godetiae }\end{array}$ & 2008 & $\mathrm{n} / \mathrm{a}^{\mathrm{b}}$ & $\mathrm{n} / \mathrm{a}$ & MT980853 & МT980881 & МT980905 & MT812213 \\
\hline 21 & CA/2 (Apple fruit) & $\mathrm{n} / \mathrm{a}$ & $\begin{array}{l}\text { Colletotrichum } \\
\text { godetiae }\end{array}$ & 2013 & $\mathrm{n} / \mathrm{a}$ & $\mathrm{n} / \mathrm{a}$ & MT980854 & MT980882 & MT980902 & MT812201 \\
\hline 22 & $\begin{array}{c}\text { 1A_01 (Apple } \\
\text { leaf spots) }\end{array}$ & $\mathrm{n} / \mathrm{a}$ & $\begin{array}{l}\text { Colletotrichum } \\
\text { fioriniae }\end{array}$ & 2018 & $\mathrm{n} / \mathrm{a}$ & $\mathrm{n} / \mathrm{a}$ & MT980848 & MT980871 & MT980890 & MT812214 \\
\hline
\end{tabular}

${ }^{a}$ The accession numbers marked with an asterisk (*) were taken from Amaral Carneiro et al. (2021). ACT, actin; GAPDH, glyceraldehyde-3-phosphate dehydrogenase; HIS3, histone 3; ITS, internal transcriber spacer.

${ }^{\mathrm{b}} \mathrm{n} / \mathrm{a}$, not available.

Table 2. Genomic regions analyzed in this study with information on the applied primer pairs, their annealing temperatures, and the expected amplicon length

\begin{tabular}{llccc}
\hline Target genomic region & \multicolumn{1}{c}{ Primer names } & $\begin{array}{c}\text { Annealing } \\
\text { temperature }\left({ }^{\circ} \mathbf{C}\right)\end{array}$ & $\begin{array}{c}\text { Amplicon } \\
\text { length (bp) }\end{array}$ & Reference \\
\hline Actin (ACT) & ACT-512F/ACT-783R & 58 & $\sim 200$ & $\begin{array}{l}\text { Carbone and Kohn (1999) } \\
\text { Glyceraldehyde-3-phosphate }\end{array}$ \\
$\begin{array}{l}\quad \text { GDFydrogenase (GAPDH) } \\
\text { Histone H3 (HIS3) }\end{array}$ & CYLH3F/CYLH3R & 60 & $\sim 200$ & (2003) \\
Internal transcribed spacer (ITS) & UP18S42/LO28S22 & 58 & $\sim 400$ & Crous et al. (2004) \\
\hline
\end{tabular}


incubated on a reciprocating shaker at $100 \mathrm{rpm}$ at $20^{\circ} \mathrm{C}$ for 10 days. After that, the mycelium was removed by filtration through three layers of sterile gauze and the filtrates were tested (Żukiewicz-Sobczak et al. 2016). API ZYM tests were carried out by placing $65 \mu \mathrm{l}$ of filtrate at the appropriate positions of the test strip and incubating the strips for 3 days at $20^{\circ} \mathrm{C}$. Apart from the initial step, the assay was performed according to the manufacturer's instructions.

Pathogenicity test. Based on molecular genetic data, three of the four Colletotrichum isolates investigated in the enzymatic assay (18DSS-BS-NTO-1-010, 18-DSS-BS-EL-1-016, and 18-DSS-BS-EL-1028) were selected to perform a pathogenicity test and prove their capacity to induce postharvest decay of apples. Pathogenicity assessment was accomplished on the cultivars Cripps Pink, Golden Delicious, and Roho 3615/Evelina. Twelve apples were used for each apple cultivar and fungal isolate. The apple fruits were washed with curd soap and incubated in a $0.5 \%$ sodium hypochlorite solution for $5 \mathrm{~min}$, rinsed with distilled water, and dried with sterile paper soaked with $70 \%$ ethanol. Conidial suspensions from 15-day-old cultures on PDA were prepared as previously described, and the conidial concentration was determined with a hemocytometer and adjusted to $10^{6}$ conidia $\mathrm{ml}^{-1}$. Three wounds were made on the equatorial plane of the fruit with a sterile piercing tool (depth $6 \mathrm{~mm} \times$ width $1 \mathrm{~mm}$ ) at $0^{\circ}, 90^{\circ}$, and $180^{\circ}$. Inoculation was performed with $20 \mu \mathrm{l}$ of spore suspension, whereas control fruits were inoculated with $20 \mu \mathrm{l}$ of sterile distilled water. Inoculated fruits were incubated for 21 days in moist chambers at $20^{\circ} \mathrm{C}$ in the dark. External symptoms were assessed, and the size of the lesions was measured at 3, 5, 7, 10, 14, and 21 days post inoculation (dpi). At the end of the experiment, three infected apples of each cultivar were selected and fungal pathogens were reisolated from the internal lesions on PDA medium. The cultures were grown for 10 days under the conditions described previously to obtain sufficient mycelium for DNA extraction. The ITS region was amplified by PCR, and Sanger sequencing was performed to confirm the identity of the isolates as described previously.

\section{Results}

Distribution and disease symptoms. In 2018 and 2019, a total of 1,071 fungal cultures was obtained from apples with symptoms of postharvest diseases that were collected in six packinghouses in South Tyrol. Only 19 of these isolates were determined to be Colletotrichum spp. Apple rot symptoms caused by this pathogen ranged from small, circular, slightly sunken, brown lesions to larger lesions with copious quantities of spores, produced in acervuli arising in concentric circles from the infection point. Most isolates were obtained from the cultivar Roho 3615/Evelina, and almost all the apples from which this genus was isolated derived from organic cultivation (Table 1).

Phylogenetic analysis. A total of 22 Colletotrichum isolates (19 obtained in the present study and three isolated in previous years at the Laimburg Research Centre) were further identified to the species level based on DNA sequence analysis of four genomic regions, ACT, GAPDH, HIS3, and ITS. Each DNA sequence acquired in the present study was individually trimmed at the same position at either end, and the final sequence lengths ranged from 184 to $186 \mathrm{bp}, 155$ to $156 \mathrm{bp}, 313$ to $317 \mathrm{bp}$, and 505 to $507 \mathrm{bp}$ for ACT, GAPDH, HIS3, and ITS, respectively. The DNA sequences obtained in the present study were aligned with those of 35 reference isolates belonging to different species of the $C$. acutatum SC available in GenBank (Table 1 and Supplementary Table S1), resulting in a concatenated multilocus alignment with 1,194 positions. The phylogenetic tree based on maximum likelihood analysis (Fig. 1) showed that most Colletotrichum isolates found in South Tyrol (16/22) clustered in the monophyletic C. godetiae group. This group, among others, comprised type specimens $117418 / 2015$ and CBS 131331 of this species, which were described in the studies by Da Lio et al. (2018) and Damm et al. (2012). A smaller number of isolates from South Tyrol (5/22) clustered in the monophyletic $C$. fioriniae group. This group contained the type specimens 117288/2015 and CBS 125396 of $C$. fioriniae, which were also described by Lio et al. (2018) and Damm et al. (2012). Only 1 of the 22 isolates from South Tyrol was grouped with type specimens CBS 113.14 and CBS 115.14 of C. salicis described by Damm et al.
(2012) (Amaral Carneiro et al. 2021). All the clades comprising distinct isolates of the three species $C$. godetiae, $C$. fioriniae, and $C$. salicis that have been identified thus far in South Tyrol were supported by bootstrap values of $100 \%$.

Pairwise distance matrices obtained separately for each genomic region and comprising DNA sequences of each isolate from South Tyrol revealed the presence of two different ITS haplotypes for $C$. fioriniae (ITS-a: 4 isolates and ITS-b: 1 isolate), whereas only one ITS haplotype (ITS-c) was observed for all 16 isolates of $C$. godetiae. The haplotypes ITS-a and ITS-b of $C$. fioriniae differed in a single point mutation (Supplementary Table S2). The 186-bp segment of ACT displayed one haplotype for all the isolates of $C$. fioriniae (ACT-a) and two haplotypes for $C$. godetiae (ACT-b: 15 isolates and ACT-c: 1 isolate). ACT-b and ACT-c differed in two point mutations (Supplementary Table S3).

The DNA sequences of the GAPDH and HIS3 genes (157 bp and $317 \mathrm{bp}$, respectively) showed the highest degree of variability among the isolates obtained in the present study. While the GAPDH gene segment revealed one haplotype for all the isolates of $C$. fioriniae (GAPDH-a), three haplotypes were found for $C$. godetiae (GAPDHb: seven isolates, GAPDH-c: eight isolates, and GAPDH-d: one isolate). The GAPDH-b, GAPDH-c and GAPDH-d sequences differed in two point mutations (Supplementary Table S4). Regarding the HIS3 gene segment, also in this case, one haplotype was found in all the isolates of $C$. fioriniae (HIS3-a) and three haplotypes were found for $C$. godetiae (HIS3-b: 12 isolates, HIS3-c: 3 isolates, and HIS3-d: 1 isolate). For the latter, variable sites were found on five positions (Supplementary Table S5). With the combination of the individual genotypes of the different genomic regions analyzed, six different multilocus genotypes (labeled from I to VI) were observed (Supplementary Tables S6). As observed in Figure 1, two multilocus genotypes of $C$. fioriniae (I and II) and four multilocus genotypes of $C$. godetiae (III to VI) were found in the present work, whereas the seventh multilocus genotype, identified as $C$. salicis, was described by Amaral Carneiro et al. (2021).

Morphological characterization. Morphological characterization focused on isolates of $C$. godetiae and $C$. fioriniae, whereas $C$. salicis was described in a previous study (Amaral Carneiro et al. 2021). The appearance of colonies of $C$. godetiae on the upper side of PDA was mostly flat with a distinct margin, the surface was covered with short floccose aerial mycelium, and the color ranged from light gray to dark gray, whereas the reverse side appeared gray to dark gray with black streaking and black spots inside the growth medium. Isolate 18-DSS-BS-EL-1-016 differed considerably from other $C$. godetiae isolates because it was flat with an undulate margin, it lacked aerial mycelium, the color was dark green olivaceous on both the upper and reverse sides, and sporulation was observed already on the third day of growth. The other $C$. godetiae isolates showed orange-salmon conidial masses and dark melanized structures similar to acervuli on the seventh day of growth. Two isolates identified as $C$. fioriniae, 18-DSS-BS-CF-1-002 and 18-DSS-BS-NTO-1-010, appeared light gray on the upper side with pink nuances and light pink on the reverse side with green-olivaceous spots. Salmon-orange conidial masses were observed to be randomly distributed on the growing mycelium after 7 days' growth. The two remaining $C$. fioriniae isolates, 18-DSS-BS-LF1-001 and 18-DSS-BS-LF-1-005, did not show pinkish mycelium typical of $C$. fioriniae (Grammen et al. 2019), but they were light gray to bluish gray with whitish margins on the upper side and whitish gray to dark green on the reverse side (Supplementary Fig. S1). No sporulation was observed in these isolates after 2 weeks of growth.

Morphological characteristics such as shape and size of conidia and colony color of two representative isolates of $C$. fioriniae and $C$. godetiae are described in Table 3, and mycelium growth rates are shown in Supplementary Figure S2. C. fioriniae samples showed a larger in vitro mycelium growth area $\left(25.1 \pm 0.9\right.$ and $\left.24.6 \pm 1.4 \mathrm{~cm}^{2}\right)$ than $C$. godetiae samples $\left(13.9 \pm 1.2\right.$ and $\left.5.7 \pm 0.1 \mathrm{~cm}^{2}\right)$ after 7 days' growth. On the 14th day, the mycelium of the two isolates of $C$. fioriniae and the C. godetiae isolate 18-DSS-BS-EL-1-028 covered the whole area of the Petri dish with PDA medium, whereas the mycelium area of the C. godetiae isolate 18-DSS-BS-EL-1-016 increased to $17.7 \pm 3.0$ $\mathrm{cm}^{2}$. Spore characteristics (length and width) were significantly different between the two species. The spores of the $C$. godetiae isolates, 
18-DSS-BS-EL-1-016 and 18-DSS-BS-EL-1-028 $(15.8 \pm 1.5$ and $14.8 \pm 1.2 \mu \mathrm{m}$, respectively), were larger than those of the $C$. fioriniae isolates, 18-DSS-BS-CF-1-002 and 18-DSS-BS-NTO-1-010 (13.9 \pm 1.2 and $13.2 \pm 0.8 \mu \mathrm{m}$, respectively; $P<0.05$ ) (Table 3 ). The shape of conidia of the two $C$. godetiae isolates were typically cylindrical, whereas the conidia of the two $C$. fioriniae isolates had an obclavate shape with acute ends. Colony color and conidia shape and size of C. salicis are described by Amaral Carneiro et al. (2021).

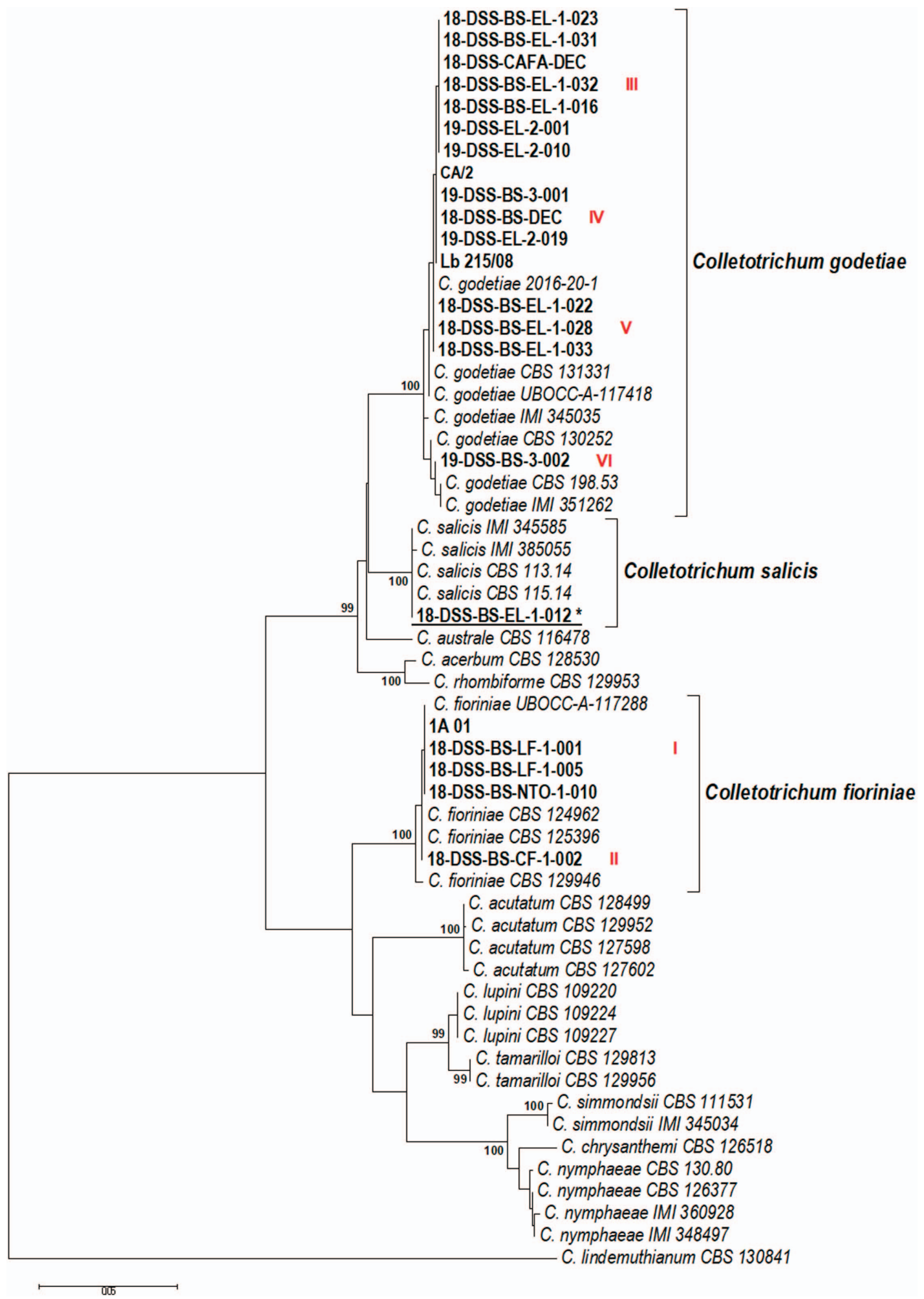

Fig. 1. Multigene phylogenetic maximum-likelihood tree constructed using MEGA X software (Kumar et al. 2018) with concatenated sequences of actin (ACT), glyceraldehyde-3-phosphate dehydrogenase (GAPDH), histone 3 (HIS3), and internal transcriber spacer (ITS) of Colletotrichum isolates causing bitter rot of apple. The phylogenetic analysis was based on an alignment with 1,194 positions. Colletotrichum lindemuthianum was used as an outgroup. Sequences of the same set of genomic regions as analyzed in the present study of 35 reference isolates representing different species of the genus were selected from the works of Da Lio et al. (2018) and Damm et al. (2012) (Supplementary Table S1). The numbers at the branches of the tree (>95\%) represent bootstrap values obtained after 1,000 replications. The 22 Colletotrichum isolates characterized in this study are highlighted in bold (19 obtained in the present study and three isolated in previous years at the Laimburg Research Centre). Roman numerals I to VI, marked in red, indicate the different multilocus genotypes found in this study. The isolate of Colletotrichum salicis described in the work of Amaral Carneiro et al. (2021) is underlined and marked with an asterisk $(*)$. 
The API ZYM test indicated enzyme activity of alkaline phosphatase, esterase lipase, acid phosphatase, naphthol-AS-BI-phosphohydrolase, $\beta$-galactosidase, and $\beta$-glucosidase for the two isolates of C. fioriniae (18-DSS-BS-CF-1-002 and 18-DSS-BS-NTO-1-010) and two isolates of $C$. godetiae (18-DSS-BS-EL-1-016 and 18-DSS-BSEL-1-028). For none of the investigated fungal isolates was activity of leucine arylamidase, valine arylamidase, cystine arylamidase, trypsin, $\alpha$-chymotrypsin, $\beta$-glucuronidase, $\alpha$-glucosidase, or $\alpha$-fucosidase observed. Positive reactions for esterase (C4) were revealed for both $C$. godetiae isolates but not for the $C$. fioriniae isolates. The isolates 18-DSS-BS-CF-1-002 (C. fioriniae) and 18-DSS-BS-EL-1-028 (C. godetiae) were found to produce $\mathrm{N}$-acetyl- $\beta$-glucosaminidase and $\alpha$-mannosidase, whereas isolate 18-DSS-BS-NTO-1-010 was the only one with a positive reaction for lipase enzyme activity (see Supplementary Table S7).

Pathogenicity test. $C$. fioriniae and $C$. godetiae were pathogenic on all three apple cultivars tested, Cripps Pink, Golden Delicious, and Roho 3615/Evelina, because $93 \%$ of the inoculated wounds were successfully infected and showed typical symptoms of bitter rot. The lesions became evident at 5 dpi on all the three apple cultivars tested, and the funnel-shaped decay of the pulp, which is typical of bitter rot, was noticed at 10 dpi. Isolate 18-DSS-BS-NTO-1-010 of C. fioriniae induced brown circular lesions with salmon-orange spore masses on the lesion surface, whereas the two $C$. godetiae isolates (18-DSS-BS-EL-1-016 and 18-DSS-BS-EL-1-028) formed dark brown to black lesions with concentric rings of black conidial masses on the lesion surface. Isolate 18-DSS-BS-EL-1-016 was the only one to induce black decay of the pulp tissue on the cultivars Cripps Pink and Golden Delicious (Supplementary Figs. S3 to S5).

C. godetiae isolates expanded faster on Golden Delicious and Cripps Pink over the entire incubation period of 21 days. At the end of the experiment, the lesion diameters induced by isolates 18-DSSBS-EL-1-016 and 18-DSS-BS-EL-1-028 were $2.4 \pm 0.6$ and $2.6 \pm$ $0.3 \mathrm{~cm}$ (mean $\pm \mathrm{SD}$ ), respectively, compared with $2.0 \pm 0.9 \mathrm{~cm}$ of isolate 18-DSS-BS-NTO-1-010. Conversely, on Roho 3615/Evelina, $C$. godetiae isolates showed higher growth rates compared with $C$. fioriniae until 14 days of incubation; however, after 21 days of incubation, the lesion diameter of $C$. fioriniae 18-DSS-BS-NTO-1-010 (3.3 \pm $1.0 \mathrm{~cm}$ ) was larger than that induced by the two $C$. godetiae isolates, 18-DSS-BS-EL-1-016 and 18-DSS-BS-EL-1-028 $(3.2 \pm 1.0 \mathrm{~cm}$ and $2.8 \pm 1.2 \mathrm{~cm}$, respectively) (Fig. 2). Based on statistical analyses of lesion diameters, Golden Delicious appeared to be more tolerant $(P<$ 0.01 ) to the Colletotrichum isolates tested, whereas Roho 3615/Evelina was the most susceptible apple cultivar in this study $(P<0.01)$.

\section{Discussion}

The present study is the first to address the pathogen species associated with bitter rot of apple in South Tyrol. Although this region is one of the largest apple-producing areas in Europe, contributing approximately $10 \%$ to apple production of the European Union, most of which are stored in sophisticated storage facilities (Autonomous Province of Bozen-Bolzano 2020), scientific data about postharvest pathogens in South Tyrol are not readily available. Several years ago, the genetic diversity of the genus Tilletiopsis spp., which can induce a postharvest disorder known as white haze as well as affect apple fruit before harvest, was assessed in South Tyrol (Baric et al. 2010). Marschall and
Rizzolli (2015) characterized the occurrence of different postharvest diseases and concluded that bitter rot of apple so far did not represent a major postharvest disease in South Tyrol. Nevertheless, knowledge about the species associated with this disease can be of practical
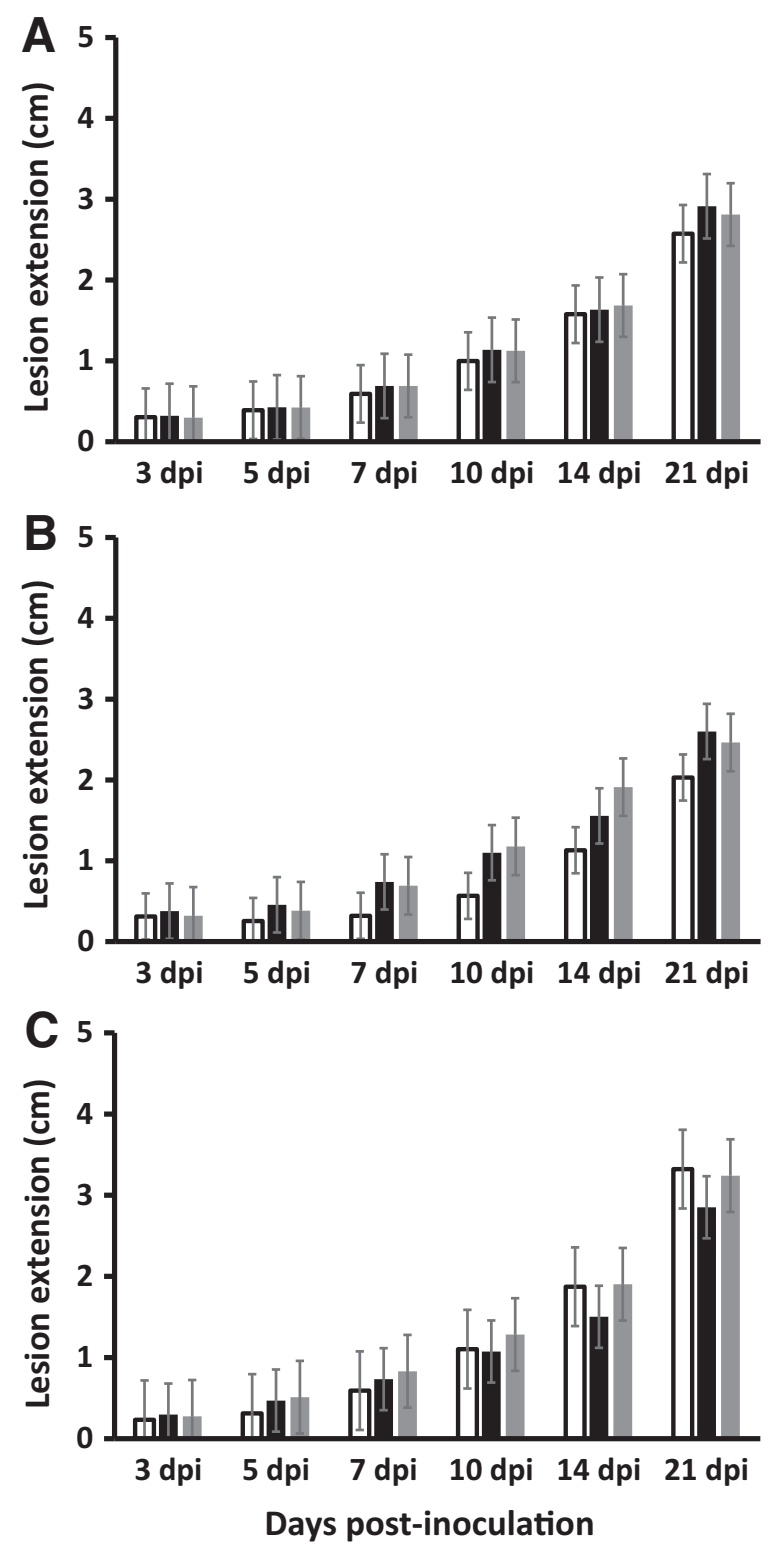

Fig. 2. Increase of the average lesion diameters ( \pm standard error) induced by three Colletotrichum isolates over a period of 21 days and measured on 6 different days post inoculation (dpi). Three apple cultivars A, Cripps Pink, B, Golden Delicious, and C, Roho 3615/Evelina were inoculated. The white column refers to Colletotrichum fioriniae isolate 18-DSS-BS-NTO-1-010, whereas the gray and black columns refer to Colletotrichum godetiae isolates 18-DSS-BS-EL-1-016 and 18-DSS-BS-EL-1-028, respectively.

Table 3. Morphological features, such as conidia shape and size and colony color, of four representative isolates of Colletotrichum fioriniae and Colletotrichum godetiae

\begin{tabular}{|c|c|c|c|c|c|c|c|}
\hline \multirow[b]{2}{*}{ Species } & \multirow[b]{2}{*}{ Isolate } & \multirow{2}{*}{$\begin{array}{c}\text { Conidia } \\
\text { length }(\mu \mathrm{m})\end{array}$} & \multirow{2}{*}{$\begin{array}{c}\text { Conidia } \\
\text { width }(\mu \mathrm{m})\end{array}$} & \multirow{2}{*}{$\begin{array}{l}\text { Ratio } \\
(\mathbf{L} / \mathbf{W})^{\mathbf{a}}\end{array}$} & \multirow{2}{*}{$\begin{array}{c}\text { Conidia } \\
\text { shape }\end{array}$} & \multicolumn{2}{|c|}{ Colony color } \\
\hline & & & & & & Upper side & Reverse side \\
\hline \multirow[t]{2}{*}{$\begin{array}{l}\text { Colletotrichum } \\
\text { fioriniae }\end{array}$} & 18-DSS-BS-CF-1-002 & $13.8 \pm 1.1$ & $5.1 \pm 0.6$ & 2.7 & Obclavate & $\begin{array}{r}\text { Light gray with } \\
\text { pink nuances }\end{array}$ & $\begin{array}{l}\text { Light pink with } \\
\text { green-olivaceous stains }\end{array}$ \\
\hline & 18-DSS-BS-NTO-1-010 & $13.8 \pm 1.2$ & $4.9 \pm 0.5$ & 2.8 & Obclavate & $\begin{array}{l}\text { Light gray with } \\
\text { pink nuances }\end{array}$ & Light pink \\
\hline Colletotrichum & 18-DSS-BS-EL-1-028 & $14.5 \pm 1.3$ & $4.9 \pm 0.6$ & 2.9 & Cylindrical & Gray & Light gray \\
\hline godetiae & 18-DSS-BS-EL-1-016 & $15.7 \pm 1.2$ & $5.8 \pm 0.5$ & 2.7 & Cylindrical & $\begin{array}{l}\text { Dark green } \\
\text { olivaceous }\end{array}$ & Dark green olivaceous \\
\hline
\end{tabular}

\footnotetext{
${ }^{a}$ L, length; $\mathrm{W}$, width.
} 
importance. The characterization of Colletotrichum spp. in the present study was performed by combining molecular genetic analysis with a morphological and pathogenicity assessment. The results of the phylogenetic analysis of multilocus DNA sequences showed that the isolates obtained from decayed apples with symptoms of bitter rot belonged to the species $C$. godetiae, $C$. fioriniae, and $C$. salicis, all being part of the C. acutatum SC (Damm et al. 2012). C. godetiae was the most common species (16/22 isolates) associated with bitter rot of apple in our study, especially on the cultivar Roho 3615/Evelina derived from organic production. In Europe, most of the identified causal agents of bitter rot of apple belong to the C. acutatum SC (Baroncelli et al. 2014; Børve and Stensvand 2015; Grammen et al. 2019; Ivic et al. 2013; Munda 2014; Nodet et al. 2016; Wenneker et al. 2016), whereas species belonging to the $C$. gloeosporioides $\mathrm{SC}$ have been reported from the United States (Munir et al. 2016), South America (Velho et al. 2015), Korea (Park et al. 2018), and France and Belgium (Grammen et al. 2019; Nodet et al. 2019).

Although an extensive sampling of apples with postharvest diseases was performed in 2018 and 2019 in South Tyrol, the number of isolates identified as the genus Colletotrichum was rather low and was observed in $1.8 \%$ of the decayed apples investigated. Among these isolates, no species belonging to the $C$. gloeosporioides complex was found. Bitter rot is considered one of the most important fungal diseases of apple responsible for major economic losses throughout the world (Khodadadi et al. 2020). However, data about the incidence of the disease principally refer to the period before harvest (Grammen et al. 2019; Khodadadi et al. 2020; Munda 2014; Munir et al. 2016; Nodet et al. 2016, 2019; Park et al. 2018; Velho et al. 2015), whereas data about the extent of postharvest losses of apple induced by Colletotrichum spp. are rarely available. It may well be the case that a higher number of isolates of Colletotrichum spp. would be obtained if the sampling were conducted in the orchards during the vegetative season than on apples that were collected after a period of prolonged storage in a controlled atmosphere.

Previous studies on the occurrence of Colletotrichum spp. on rotten apples after several months of storage in Italy are few, and they reported the presence of $C$. acutatum in the regions of EmiliaRomagna and South Tyrol (Mari et al. 2011; Marschall and Rizzolli 2015). The identification of $C$. acutatum isolates in the work by Mari et al. (2011) was based on the description of morphological characteristics, such as colony color and conidia shape and size, and was further supported by $100 \%$ identification of the DNA sequence of the ITS region with a GenBank accession (AB626881), which was identified as C. acutatum (syn. Glomerella acutata). The ITS sequence with the accession number AB626881 was submitted to GenBank in 2011, and identification of the fungal isolate from which the DNA sequence was derived as $C$. acutatum was accomplished before the taxonomic revision of the $C$. acutatum SC performed by Damm et al. (2012). Therefore, it is probable that the fungal isolate was not identified as $C$. acutatum sensu stricto but as belonging to the C. acutatum SC.

Considering the revised species nomenclature within the $C$. acutatum SC, DNA sequences of the ITS region representative of several species of the complex described by Da Lio et al. (2018) and Damm et al. (2012) were reanalyzed together with GenBank accession AB626881 and all the ITS sequences obtained in the present study (Supplementary Fig. S6). The phylogenetic tree revealed that GenBank accession AB626881 did not cluster in the C. acutatum clade sensu stricto but in the monophyletic $C$. fioriniae group. Moreover, the DNA sequence showed $100 \%$ identity with the sequence of $C$. fioriniae type specimen CBS 125396 and with one of the isolates obtained in the present study (18-DSS-BS-CF-1-002); Supplementary Fig. S6). This finding would imply that $C$. fioriniae is not a new species in Italy but has already been present as a causal agent of bitter rot of apple since at least 2011. Similarly, we can speculate that $C$. acutatum reported by Marschall and Rizzolli (2015) refers to the SC, but the main causal agent of bitter rot of apple in this area has in fact been the species C. godetiae. This assumption is supported by the fact that two Colletotrichum isolates obtained from Laimburg Research Centre that were collected in 2008 and 2013 were identified as $C$. godetiae by MLST in the present study. Furthermore, the finding of four different multilocus genotypes among 16 isolates of $C$. godetiae investigated in the present study may be an indication that this species has been present in this geographic area for a longer time. To the best of our knowledge, $C$. godetiae and $C$. fioriniae have so far never been mentioned as postharvest pathogens of apple in Italy, although there are several indications that these species have been isolated from apples with bitter rot for at least a decade. Consequently, all the isolates obtained from apple in this geographic area and previously identified as C. acutatum would need to undergo a revision.

The recognition of ITS as one of the official DNA barcode markers for identification of fungal species has been of great benefit to the scientific community (Schoch et al. 2012). To identify an unknown fungus, generally BLAST (Boratyn et al. 2013), which is associated with the National Center for Biotechnology Information (NCBI) database, is used to compare the ITS sequence fragment of a query to all other DNA sequences contained in the database to identify identical or most similar matches. The BLAST search typically relies on the nucleotide collection, in which a query sequence is compared with all the sequences present in the database. However, it has been recommended that BLAST search identifications against GenBank should be made with caution, because approximately $27 \%$ of fungal ITS sequences contained in GenBank were submitted with insufficient taxonomic identification (Raja et al. 2017). To avoid misidentification of fungi, it is possible to perform a more stringent BLAST search by checking the "sequences from type material" box on the general BLAST page and, whenever possible, by selecting DNA sequences of type material or other authenticated isolates for phylogenetic analyses. In addition to this, several curated databases have been established containing DNA sequences of the ITS region and other ribosomal and protein-coding genes of different groups of fungi (Federhen 2012; Raja et al. 2017). In the specific case of Colletotrichum, the database Q-bank has a dedicated section for the identification of fungi, which is curated by Dr. Ulrike Damm, and in which the taxonomic description and MLST data of various type specimens are provided (https://qbank.eppo.int/ fungi/) (EPPO-Q-bank 2021).

In the present study, four molecular markers were analyzed by Sanger sequencing, ACT, GAPDH, HIS3, and ITS to be considered in the multigene phylogenetic analysis. Nevertheless, each of the four gene segments alone proved to be a good marker to distinguish C. fioriniae, C. godetiae, and C. salicis from each other but also from other species of the $C$. acutatum SC. The highest degree of genetic distance at the interspecific level was found for partial DNA sequences of the GAPDH and HIS3 genes, which also represent recommended markers to be used for species identification within the C. acutatum SC (Da Lio et al. 2018; Damm et al. 2012). Damm et al. (2012) analyzed six gene regions to obtain a phylogeny (ITS, TUB2, HIS3, GAPDH, CHS-1, and ACT) and showed that not all gene fragments were informative to be used in phylogenetic studies. For example, CHS-1 is not suitable for separating $C$. godetiae from other species in the $C$. acutatum $\mathrm{SC}$, and TUB2 was insufficient to make a reliable distinction between Colletotrichum spp. in the study by Grammen et al. (2019). In the present work, it was not possible to obtain a specific PCR product for CHS-1. Despite intensive efforts to optimize the PCR reaction, multiple bands were observed on the agarose gel. The same results were obtained for the TUB2 region when using the primers described by Damm et al. (2012) and Grammen et al. (2019).

Colletotrichum species were traditionally classified using morphological features based on colony color and the shape and size of conidia. However, the investigation of morphological characters performed in the present study, in particular the colony features, showed more variability in phenotypic traits than Grammen et al. (2019). For example, the pinkish colony color and salmon- to orange-colored conidial masses of $C$. fioriniae were not observed in the isolates 18DSS-BS-LF-1-001 and 18-DSS-BS-LF-1-005. Furthermore, the colony color of $C$. godetiae isolates in the present study ranged from light gray to dark gray, whereas the reverse side appeared gray to dark gray with black streaking and black spots inside the growth medium; Grammen et al. (2019) reported the color of the colonies as light brown on the upper side and a mix of orange, gray, and yellow on the reverse side. In fact, several studies have demonstrated that the morphological traits may not be stable and may differ in dependence of the 
experimental conditions. Thus, the morphological approach alone is not reliable for species discrimination within the genus (Cannon et al. 2012; Damm et al. 2012; Velho et al. 2015; Weir et al. 2012).

In this work, extracellular enzymatic profiles of two representative isolates of each species, $C$. fioriniae and $C$. godetiae, were investigated after 10 days of growth in liquid nutrient medium, revealing a high degree of similarity, such as the common activity of alkaline phosphatase, acid phosphatase, and naphthol-AS-BI-phosphohydrolase. These enzymes are necessary in the degradation of organic phosphorus compounds, which are components of the phospholipid bilayer of cell membranes (De Oliveira et al. 2013). Likewise, esterase lipases, important enzymes in the breakdown of ester bonds, which link the monomers of fatty acids such as cutin, were produced by all the isolates. The extracellular enzymes released by plant pathogenic fungi are connected to their ability to degrade the plant cuticle and cell wall components, which causes the onset of the disease. Few studies have focused on extracellular enzymatic profiles of the genus Colletotrichum. Fernando et al. (2001) showed that isolates of $C$. acutatum are capable of secreting cellulolytic enzymes, such as $\beta$-glucosidase, both in vitro and in vivo. Other works demonstrated the ability of Colletotrichum fructicola and $C$. gloeosporioides to produce hydrolytic enzymes such as amylases, pectinases, and lipase, which are important in pathogenesis (Armesto et al. 2019; Velho et al. 2018).

In the present work, we observed that all the investigated Colletotrichum isolates manifested activity of $\beta$-glucosidase, which plays a key role in the degradation of cellulose and $\beta$-galactosidase and represents one of the cell wall-modifying enzymes that plays a role in fruit ripening and softening (Tiwari et al. 2013; Yang et al. 2018). In fact, in the pathogenicity test, both C. fioriniae (18-DSS-BS-NTO-1-010) and C. godetiae (18-DSS-BS-EL-1-016 and 18-DSS-BS-EL-1-028) were able to colonize and cause putrefaction of the fleshy pulp tissue independent of the apple cultivar. However, some differences were noticed: esterase C4 was observed only in C. godetiae samples and lipase (C14) in isolate 18-DSS-BS-NTO-1-010 (C. fioriniae). Moreover, isolates 18-DSS-BSCF-1-002 (C. fioriniae) and 18-DSS-BS-EL-1-0128 (C. godetiae) differed from the others because they produced $\mathrm{N}$-acetyl- $\beta$-glucosaminidase and $\alpha$-mannosidase, enzymes involved in the degradation of chitin and responsible for the hydrolysis of mannan and other hemicellulose components, respectively (Eades and Hintz 2000).

The API ZYM system is a semiquantitative method designed to detect the activity of 19 enzymes in a single test, and it has been applied as a simple and fast tool for differentiation of bacterial and fungal species, especially for microorganisms that cause human diseases and are used in food processing (Colombo et al. 2018; Humble et al. 1977; Tharagonnet et al. 1977; Tofalo et al. 2011; ZukiewiczSobczak et al. 2016). A few studies concerning phytopathogens exist; however, to the best of our knowledge, this method has never been applied for the enzymatic characterization of fungal species belonging to the genus Colletotrichum. De Oliveira et al. (2013) recommended the API ZYM test for the characterization of the fungus Corynespora cassiicola, which displays a wide host plant range. Although differences in enzymatic profiles have been observed, the small number of samples involving only five isolates did not permit obtaining more conclusive results (De Oliveira et al. 2013). Likewise, some enzymatic profile differences were observed in the present study; however, more samples of $C$. fioriniae and $C$. godetiae should be tested to confirm and reproduce these results.

Breeding new apple cultivars and rootstocks is a crucial factor for the implementation of more sustainable fruit-growing systems such as organic agriculture. Some of the new apple cultivars that have increasingly been grown in organic production systems are Coop 38/Gold Rush, Roho 3615/Evelina, and SQ 159/Natyra because they carry resistance genes to apple scab (Kienzle and Kelderer 2017). In 2001, Biggs and Miller (2001) demonstrated that some scab-resistant apple cultivars are particularly susceptible to $C$. acutatum, however. For example, Pristine was described as the most susceptible cultivar, whereas Enterprise showed a high degree of susceptibility, and Coop 38/Gold Rush presented moderate levels of susceptibility.

The total organic farming area in the countries of the European Union was 13.4 million ha in 2018 and is expected to grow in the coming years (Eurostat 2020). In Italy, organic apples were grown on 8,235 ha in 2019 (Sinab 2020). As for apple production in South Tyrol, approximately $10 \%$ of the cultivation area is organically managed (Südtiroler Bauernbund 2017) and approximately 60,500 metric tons of organic apples were harvested in 2019 (Autonomous Province of Bozen-Bolzano 2020). A remarkable observation in the present work was that 18 of 19 Colletotrichum isolates were obtained from organically grown apples. Moreover, 13 of 16 C. godetiae isolates were obtained from Roho 3615/Evelina, whereas three of the four $C$. fioriniae isolates found in our 2-year sampling survey were obtained from the cultivar Coop 38/Gold Rush, and one was isolated from SQ 159/Natyra. Considering that one of the goals of South Tyrolean agriculture is to double the area of organically managed land in the next years (Südtiroler Bauernbund 2017), one would expect a further increase in the cultivation of scab-resistant but potentially Colletotrichum-susceptible apple cultivars.

For this reason, research should focus on assessing the susceptibility of the most important apple cultivars grown organically in South Tyrol to Colletotrichum species but also to other preharvest and postharvest pathogens. Furthermore, it is crucial to conduct a large-scale survey on the incidence of Colletotrichum in organically and conventionally managed orchards and compare the incidence and species composition to those occurring after a period of prolonged storage in a controlled atmosphere. This survey would provide insight into whether geographic distinctiveness or cultivation practices in this region influence the frequency of various species of the genus Colletotrichum and their ability to remain latent in apple fruit. An additional aspect to emphasize is that species of the genus Colletotrichum cause devastating diseases on a wide range of fruit crops and that $C$. acutatum SC isolated from other host species were shown to be pathogenic on apple fruit as well (Dowling et al. 2020; Grammen et al. 2019). Zapparata et al. (2017) reported $C$. godetiae as a causal agent of grape berry rot (Vitis vinifera) in the Tuscany region (Italy). Considering that grapevine is the second most important permanent culture in South Tyrol and vineyards cover an area of 5,553 ha (Autonomous Province of Bozen-Bolzano 2020), it is important to understand whether and to which degree crossinfections with Colletotrichum among grapevine and apple can occur.

The present study demonstrated that different species of the $C$. $a c u$ tatum SC are present as postharvest pathogens of apple in South Tyrol but so far play a minor role compared with Penicillium expansum, Phlyctema vagabunda (syn. Neofabraea alba and Neofabraea vagabunda), or Botrytis cinerea (unpublished data). Nevertheless, the expansion of organic apple production and the conversion to new potentially susceptible cultivars could be factors leading to an increase of the incidence of bitter rot. Therefore, further knowledge about the biology and epidemiology of Colletotrichum spp. is of utmost importance to predict whether and to which degree bitter rot could become a problem in South Tyrol, as was observed in other apple-growing areas.

\section{Acknowledgments}

The authors thank Klaus Marschall and Sabine Öttl for kindly providing isolates of Colletotrichum spp. from the isolate collection of the Laimburg Research Centre and Jacob Egger for technical support during the pathogenicity assessment. The authors also are grateful to the South Tyrolean Fruit Growers cooperatives for providing samples of apples with postharvest diseases. The Department of Innovation, Research and University of the Autonomous Province of Bozen-Bolzano is acknowledged for covering the article publication charges.

\section{Literature Cited}

Amaral Carneiro, G., and Baric, S. 2021. Single-spore isolation protocol for characterisation of postharvest pathogens causing bitter rot of apple in South Tyrol. Acta Hortic. in press.

Amaral Carneiro, G., Storti, A., and Baric, S. 2021. First report of Colletotrichum salicis causing bitter rot of apple in Italy. Plant Dis. 105:224.

Armesto, C., Gonçalves Martins Maia, F., Pereira Monteiro, F., and Sobral de Abreu, M. 2019. Exoenzymes as a pathogenicity factor for Colletotrichum gloeosporioides associated with coffee plants. Summa Phytopathol. 45:368-373.

Autonomous Province of Bozen-Bolzano. 2020. Agrar- und Forstbericht 2019. Department for Agriculture, Forestry, Civil Protection and Local Communities of the Autonomous Province of Bozen-Bolzano. http://www.provinz.bz.it/ land-forstwirtschaft/landwirtschaft/agrar-forstbericht.asp

Baric, S., Lindner, L., Marschall, K., and Dalla Via, J. 2010. Haplotype diversity of Tilletiopsis spp. causing white haze in apple orchards in northern Italy. Plant Pathol. 59:535-541. 
Baroncelli, R., Sreenivasaprasad, S., Thon, M. R., and Sukno, S. A. 2014. First report of apple bitter rot caused by Colletotrichum godetiae in the United Kingdom. Plant Dis. 98:1000.

Biggs, A. R., and Miller, S. S. 2001. Relative susceptibility of selected apple cultivars to Colletotrichum acutatum. Plant Dis. 85:657-660.

Boratyn, G. M., Camacho, C., Cooper, P. S., Coulouris, G., Fong, A., Ma, N., Madden, T. L., Matten, W. T., McGinnis, S. D., Merezhuk, Y., Raytselis, Y., Sayers, E. W., Tao, T., Ye, J., and Zaretskaya, I. 2013. BLAST: a more efficient report with usability improvements. Nucleic Acids Res. 41:29-33.

Børve, J., and Stensvand, A. 2015. Colletotrichum acutatum on apple in Norway. IOBC WPRS Bull. 110:151-157.

Cannon, P. F., Damm, U., Johnston, P. R., and Weir, B. S. 2012. Colletotrichum: current status and future directions. Stud. Mycol. 73:181-213.

Carbone, I., and Kohn, L. M. 1999. A method for designing primer sets for speciation studies in filamentous ascomycetes. Mycologia 91:553-556.

Cassago, A., Panepucci, R. A., Tortella Baião, A. M., and Henrique-Silva, F. 2002. Cellophane based mini-prep method for DNA extraction from the filamentous fungus Trichoderma reesei. BMC Microbiol. 2:14.

Choi, Y. W., Hyde, K. D., and Ho, W. W. H. 1999. Single spore isolation of fungi. Fungal Divers. 3:29-38.

Colombo, M., Castilho, N. P. A., Todorov, S. D., and Nero, L. A. 2018. Beneficial properties of lactic acid bacteria naturally occurring in dairy production. BMC Microbiol. 18:219.

Crous, P. W., Groenewald, J. Z., Risède, J. M., Simoneau, P., and Hywel-Jones, N. L. 2004. Calonectria species and their Cylindrocladium anamorphs: species with sphaeropedunculate vesicles. Stud. Mycol. 50:415-430.

Da Lio, D., Cobo-Díaz, J. F., Masson, C., Chalopin, M., Kebe, D., Giraud, M., Verhaeghe, A., Nodet, P., Sarrocco, S., Le Floch, G., and Baroncelli, R. 2018. Combined metabarcoding and multi-locus approach for genetic characterization of Colletotrichum species associated with common walnut (Juglans regia) anthracnose in France. Sci. Rep. 8:10765.

Damm, U., Cannon, P. F., Woudenberg, J. H. C., and Crous, P. W. 2012. The Colletotrichum acutatum species complex. Stud. Mycol. 73:37-113.

De Oliveira, C. R., De Oliveira, R. R., Bordon, M. C., Tessmann, D. J., SchwanEstrada, F. R. K., and Vida, B. J. 2013. Enzymatic characterization of Corynespora cassiicola isolates using the API-ZYM ${ }^{\circledR}$ system. J. Phytopathol. 161:210212.

Dowling, M., Peres, N., Villani, S., and Schnabel, G. 2020. Managing Colletotrichum on fruit crops: a 'complex' challenge. Plant Dis. 104:2301-2316.

Eades, C. J., and Hintz, W. E. 2000. Characterization of the $\alpha$-mannosidase gene family in filamentous fungi: N-glycan remodelling for the development of eukaryotic expression systems. Biotechnol. Bioprocess Eng. 5:227-233.

EPPO-Q-bank. 2021. A database to support plant pest diagnostic activities. https://qbank.eppo.int/search?kw=Colletotrichum

Eurostat. 2020. Organic farming statistics: statistics explained. European Commission (EU). https://ec.europa.eu/eurostat/statistics-explained/index.php/ Organic_farming_statistics

Faedda, R., Agosteo, G. E., Schena, L., Mosca, S., Frisullo, S., Magnano Di San Lio, G., and Cacciola, S. O. 2011. Colletotrichum clavatum sp. nov. identified as the causal agent of olive anthracnose in Italy. Phytopathol. Mediterr. 50:283-302.

Federhen, S. 2012. The NCBI taxonomy database. Nucleic Acids Res. 40:136-143.

Fernando, T. H. P. S., Jayasinghe, C. K., and Wijesundera, R. L. C. 2001. Cell wall degrading enzyme secretion by Colletotrichum acutatum, the causative fungus of secondary leaf fall of Hevea brasiliensis. Mycol. Res. 105:195-201.

Giraud, M. 2012. Maladies de conservation de la pomme: biologie et épidémiologie des gloeosporioses. Infos CTIFL 285:21-29.

Grammen, A., Wenneker, M., Van Campenhout, J., Pham, K. T. K., Van Hemelrijck, W., Bylemans, D., Geeraerd, A., and Keulemans, W. 2019. Identification and pathogenicity assessment of Colletotrichum isolates causing bitter rot of apple fruit in Belgium. Eur. J. Plant Pathol. 153:253-269.

Guerber, J. C., Liu, B., Correll, J. C., and Johnston, P. R. 2003. Characterization of diversity in Colletotrichum acutatum sensu lato by sequence analysis of two gene introns, mtDNA and intron RFLPs, and mating compatibility. Mycologia 95:872.

Humble, M. W., King, A., and Phillips, I. 1977. API ZYM: a simple rapid system for the detection of bacterial enzymes. J. Clin. Pathol. 30:275-277.

Ivic, D., Voncina, D., Sever, Z., Simon, S., and Pejic, I. 2013. Identification of Colletotrichum species causing bitter rot of apple and pear in Croatia. J. Phytopathol. 161:284-286.

Khodadadi, F., González, J. B., Martin, P. L., Giroux, E., Bilodeau, G. J., Peter, K. A., Doyle, V. P., and Aćimović, S. G. 2020. Identification and characterization of Colletotrichum species causing apple bitter rot in New York and description of $C$. noveboracense sp. nov. Sci. Rep. 10:11043.

Kienzle, J., and Kelderer, M. 2017. Growing organic apples in Europe. Pages 551-578 in: Achieving Sustainable Cultivation of Apples. K. Evans, ed. Burleigh Dodds Science Publishing Limited, London, United Kingdom.

Kumar, S., Stecher, G., Li, M., Knyaz, C., and Tamura, K. 2018. MEGA X: molecular evolutionary genetics analysis across computing platforms. Mol. Biol. Evol. 35:1547-1549.

Levesque, C. A., and de Cock, A. W. A. M. 2004. Molecular phylogeny and taxonomy of the genus Pythium. Mycol. Res. 108:1363-1388.
Mari, M., Guidarelli, M., Martini, C., and Spadoni, A. 2011. First report of Colletotrichum acutatum causing bitter rot on apple in Italy. Plant Dis. 96:144.

Marschall, K., and Rizzolli, W. 2015. Im Südtiroler Apfelanbau auftretende Lagerfäulen: Biologie der Erreger und ihre Bekämpfung [Apple Storage Diseases in South Tyrol: Biology And Control]. Pages 117-119 in: Bericht der ALVA-Jahrestagung "Bioökonomie in der Primärproduktion", Graz, Austria.

Munda, A. 2014. First report of Colletotrichum fioriniae and C. godetiae causing apple bitter rot in Slovenia. Plant Dis. 98:1282.

Munir, M., Amsden, B., Dixon, E., Vaillancourt, L., and Ward Gauthier, N. A. 2016. Characterization of Colletotrichum species causing bitter rot of apple in Kentucky orchards. Plant Dis. 100:2194-2203.

Nodet, P., Baroncelli, R., Faugère, D., and Le Floch, G. 2016. First report of apple bitter rot caused by Colletotrichum fioriniae in Brittany, France. Plant Dis. 100:1497.

Nodet, P., Chalopin, M., Crété, X., Baroncelli, R., and Le Floch, G. 2019. First report of Colletotrichum fructicola causing apple bitter rot in Europe. Plan Dis. 103:1767.

Park, M. S., Kimb, B. R., Park, I. H., and Hahmb, S. S. 2018. First report of two Colletotrichum species associated with bitter rot on apple fruit in Korea: $C$. fructicola and C. siamense. Mycobiology 46:154-158.

R Development Core Team. 2019. R: A Language and Environment for Statistical Computing. R Foundation for Statistical Computing, Vienna, Austria.

Raja, H. A., Miller, A. N., Pearce, C. J., and Oberlies, N. H. 2017. Fungal identification using molecular tools: a primer for the natural products research community. J. Nat. Prod. 80:756-770.

Schoch, C. L., Seifert, K. A., Huhndorf, S., Robert, V., Spouge, J. L., Levesque, C. A., and Chen, W., and Fungal Barcoding Consortium. 2012. Nuclear ribosomal internal transcribed spacer (ITS) region as a universal DNA barcode marker for fungi. Proc. Natl. Acad. Sci. USA 109:6241-6246.

Shivas, R. G., and Tan, Y. P. 2009. A taxonomic re-assessment of Colletotrichum acutatum, introducing $C$. fioriniae comb. et stat. nov. and $C$. simmondsii sp. nov. Fungal Divers. 39:111-122.

Sinab. 2020. Bio in cifre 2020. Sistema d'Informazione Nazionale sull'Agricoltura Biologica. MiPAAF. http://www.sinab.it/bionovita/bio-cifre-2020-i-datinazionali-sul-biologico

Sreenivasaprasad, S., and Talhinhas, P. 2005. Genotypic and phenotypic diversity in Colletotrichum acutatum, a cosmopolitan pathogen causing anthracnose on a wide range of hosts. Mol. Plant Pathol. 6:361-378

Südtiroler Bauernbund. 2017. Biokonzept 2025, Broschüre No. 24. Südtiroler Bauernbund, Bozen, Italy.

Sutton, T. B., Aldwinckle, H. S., Agnello, A. M., and Walgenbach, J. F. 2014 Compendium of Apple and Pear Diseases and Pests, 2nd Ed. American Phytopathological Society, St. Paul, MN

Taylor, J. W., and Fisher, M. C. 2003. Fungal multilocus sequence typing: it's not just for bacteria. Curr. Opin. Microbiol. 6:351-356.

Tharagonnet, D., Sisson, P. R., Roxby, C. M., Ingham, H. R., and Selkon, J. B. 1977. The API ZYM system in the identification of gram-negative anaerobes. J. Clin. Pathol. 30:505-509.

Tiwari, P., Misra, B. N., and Sangwan, N. S. 2013. $\beta$-glucosidases from the fungus Trichoderma: an efficient cellulase machinery in biotechnological applications. BioMed Res. Int. 203:735.

Tofalo, R., Schirone, M., Telera, G. C., Manetta, A. C., Corsetti, A., and Suzzi, G. 2011. Influence of organic viticulture on non-Saccharomyces wine yeast populations. Ann. Microbiol. 61:57-66.

Velho, A. C., Alaniz, S., Casanova, L., Mondino, P., and Stadnik, M. J. 2015 New insights into the characterization of Colletotrichum species associated with apple diseases in southern Brazil and Uruguay. Fungal Biol. 119:229-244.

Velho, A. C., Mondino, P., and Stadnik, M. J. 2018. Extracellular enzymes of Colletotrichum fructicola isolates associated to apple bitter rot and Glomerella leaf spot. Mycology 9:145-154.

Weir, B. S., Johnston, P. R., and Damm, U. 2012. The Colletotrichum gloeosporioides species complex. Stud. Mycol. 73:115-180.

Wenneker, M., Pham, K. T. K., Lemmers, M. E. C., de Boer, F. A., van der Lans, A. M., van Leeuwen, P. J., and Hollinger, T. C. 2016. First report of Colletotrichum godetiae causing bitter rot on 'Golden Delicious' apples in the Netherlands. Plant Dis. 100:218.

Wenneker, M., and Thomma, B. P. H. J. 2020. Latent postharvest pathogens of pome fruit and their management: from single measures to a systems intervention approach. Eur. J. Plant Pathol. 156:663-681.

Wharton, P., and Diéguez-Uribeondo, J. 2004. The biology of Colletotrichum acutatum. An. Jardin Botanico Madr. 1979 61:3-22.

Yang, H., Liu, J., Dang, M., Zhang, B., Li, H., Meng, R., Qu, D., Yang, Y., and Zhao, Z. 2018. Analysis of $\beta$-galactosidase during fruit development and ripening in two different texture types of apple cultivars. Front. Plant Sci. 9:1-13

Zapparata, A., Da Lio, D., Sarrocco, S., Vannacci, G., and Baroncelli, R. 2017. First report of Colletotrichum godetiae causing grape (Vitis vinifera) berry rot in Italy. Plant Dis. 101:1051.

Żukiewicz-Sobczak, W. A., Cholewa, G., Sobczak, P., Silny, W., Nadulski, R., Wojtyła-Buciora, P., and Zagórski, J. 2016. Enzymatic activity of fungi isolated from crops. Adv. Dermatol. Allergol. 33:457-463. 